\title{
The Journal of
}

\section{Laryngology and Otology}

\author{
EDITED BY \\ G. H. BATEMAN \\ ASSISTANT EDITOR \\ LIONEL TAYLOR
}

Contents

Sir VICTOR NEguS

Naso-alveolar Cysts: Aetiology, Presentation AND TREATMENT: SiX CASES ARE REPORTED.

Transzygomatic Approach to the Petrous Apex With a Record of Three Cases . .

The Soctal Development of Deaf Children -

The Place of Myringotomy in the Management of Secretory Otitis Media in Children .

Severe Reduction of Hearing and Vestibular INVOLVEMENT CAUSED BY VIONACTAN ${ }^{\circledR}$.

NarRow Field Mastoidectomy in TyMpanoplasty. On the Treatment of Parotid Fistulae •

Myringoplasty by Homogenous Vein Graft. .

\section{Clinical Records-}

The Auditory Eyoked Cortical Response as AN INDEX OF HEARING IN PRACTICAL AUdIOMETRY

MUltiple Neurofibromatosis INVOLVing the VIIITH NERVE

Congenital Unilateral Choanal Atresia Associated with a RHINOlith. . .

Membranous Total Closure of the External AUdITORY CANAL . $\quad$. . . .

G. P. WALSH-WARING

LEWIS LABIB SAMY and ISKANDER H. GIRGIS EDMUND CRITCHLEY

J. C. ARCHARD

HaNs Jelert J. Nowinski A. C. Arulpragasam J. F. O. Mitchell

H. A. BEAGLEY and J. J. KNIGHT

Helio Martins and JATME T. BenIteZ

DAOUD S. ALI

A. Palva and S. SUURKARI

General Notes

London

\section{Headley Brothers}

rog Kingsway $\mathrm{WC}_{2}$ 


\title{
The Journal of \\ Laryngology \\ and Otology
}

(FOUNDED in 1887 by MORBLL MACKENZIE and NORRIS WOLFENDEN)

\author{
EDITED BY \\ G. H. BATEMAN
}

ASSISTANT EDTTOR

LIONEL TAYLOR

x. Original articles which have not been published elsewhere are invited and should be sent to the Editor. They are considered for publication on the understanding that they are contributed to this Journal solely. Reproduction elsewhere, in whole or in part, is not permitted without the previous written consent of the Author and Editor and the customary acknowledgment must be made.

2. Manuscripts should be typewritten, on one side only of the paper, and well spaced. Captions to illustrations should be typed on a separate sheet and sent at the same time as original photographs, etc.

The Harvard system of recording references should be used, e.g. Grken, C., and Brown, D. (1951) J. Laryng., 65, 33. Abbreviations of Journals should follow the style recommended in World Medical Periodicals, published by World Health Organization, 1952.

It is most important that authors should verify personally the accuracy of every reference before submitting a paper for publication.

3. Galley proofs and engraver's proofs of illustrations are sent to the author. Corrections, which should be kept to a minimum, must be clearly marked, and no extra matter added. Proofs should be returned within s days.

4. Illustration blocks will normally be held by the Printers for three years, after which they will be destroyed. Any author is entitled to have these returned to him, but a request for this must be sent within three years of the appearance of the article, to Headley Brotrers, tog Kingsway, London, WC2. Coloured illustrations will be charged to authors, unless a special grant is authorized by the Editor.

5. Orders for reprints must be sent when returning galley proofs, and for this purpose special forms are supplied.

6. Authors of original communications on Oto-Laryngology in other journals are invited to send a copy, or two reprints, to the Journal of Laryngology. If they are willing, at the same time, to submit their own abstract (in English, French, Italian, or German) it will be welcomed.

7. Editorial communications may be addressed to THE EDrror, Journal of Laryngology, c/o HeAdlex Brothers, rog Kingsway, London, WC2.

8. The annual subscription is five guineas sterling (U.S.A. \$r5) post free, and payable in advance.

9. Single copies will be on sale at I2s. 6d. each; copies of parts up to Vol. LXIII which are available may be purchased at $7 \mathrm{~s} .6 \mathrm{~d}$. each.

ro. All subscriptions, advertising and business communications should be sent to the publishers, Headeex Brothers, 109 Kingsway, London, WC.2.

\section{United States of America}

Orders for this Journal may be sent through local booksellers, or to STECHERT-HAFNER, INC., 3I-33 East Ioth Street, New York, or direct to the publishers, Headery Brothers, rog Kingsway, London, WC2, England.

C. Journal of Laryngology and Otology, 1967 


\section{O N T E N T S}

PAGE

Sir Victor Negus

Naso-alveolar Cysts: Aetiology, Presentation and Treatment: Stx

CASes ARE Reported. G. P. Walsh-Waring (London) . . 263

Transzygomatic Approach to the Petrous Apex with a Record of Three Cases. Lewis Labib Samy and Iskander H. Girgis (Cairo) . . . . . . . . . . 277

The Social Development of Deaf Children. Edmund Critchley (Mogerhanger) . $. \quad . \quad . \quad . \quad . \quad . \quad . \quad 29 \mathrm{I}$

The Place of Myringotomy in the Managenent of Secretory Otitis Media in Children. J. C. Archard (London) . . . 309

Severe Reduction of Hearing and Vestibular Involvement Caused BY Vionactan ${ }^{\circledR}$. Hans Jelert (Aalborg, Denmark) . . . 3I7

Narrow Field Mastoidectomy in Tympanoplasty. J. Nowinski

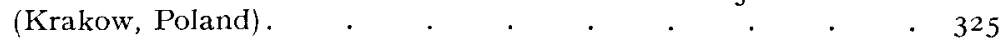

Ox the Treatment of Parotid Fistclae. A. C. Arulpragasam (Kandy, Ceylon) .

Myringoplasty by Homogenous Vein Graft. J. F. O. Mitchell (Dundee) 339

Clinical Recorbs-

The Auditory Evoked Cortical Response as an Index of Hearing in Practical Audiometry. H. A. Beagley and J. J. Knight (London) . . . . . . . . .

Multiple Neurofibromatosis Involving the Viitth Nerve. Helio Martins and Jaime T. Benitez (Detroit, Michigan) • . 353

Congenital Unilateral Choanal Atresia Associated with a Rhinolith. Daoud S. Ali (Baghdad) . . . . . 359

Mexibranous Total Closure of the External Auditory Canal. A. Palva and S. Suurkari (Oulu, Finland) . $\quad . \quad . \quad 363$

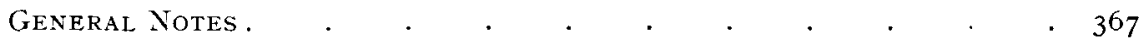




\section{KAMPLEX \\ AUDIOMETRIC EQUIPMENT}

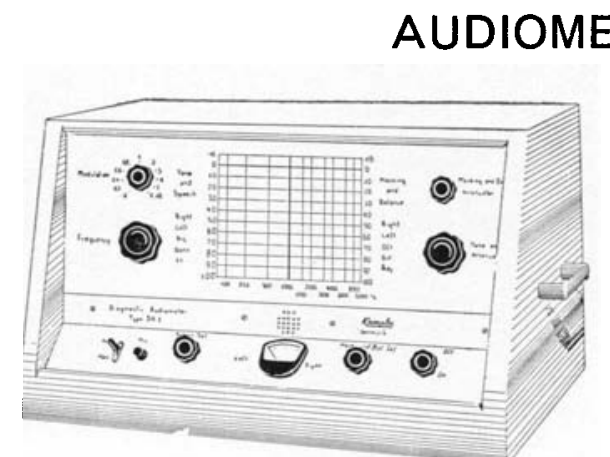

SCREENING PORTABLE TA16

DIAGNOSTIC PORTABLE TA15

CLINIC AUDIOMETER DA1

DOUBLE CHANNEL DA2

AUTOMATIC AUDIOMETER

CLINIC AUDIOMETER DA1

ACOUSTIC IMPEDANCE

APPARATUS ZA2

PNEUMOMETER ZP1

SKIN RESISTANCE

APPARATUS RA4
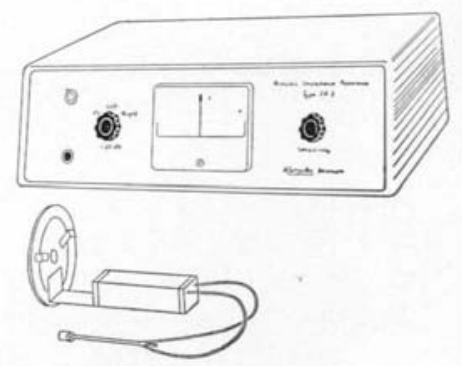

SOUND LEVEL METER GA6

VISIBLE SPEECH APPARATUS

AUDITORY TRAINERS

Write for full catalogue and detailed descriptions to:

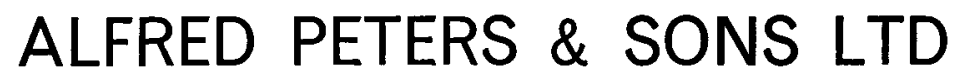

51 GELL STREET, SHEFFIELD 3

Please mention The Journal of Laryngology and Otology when replying to advertisements 


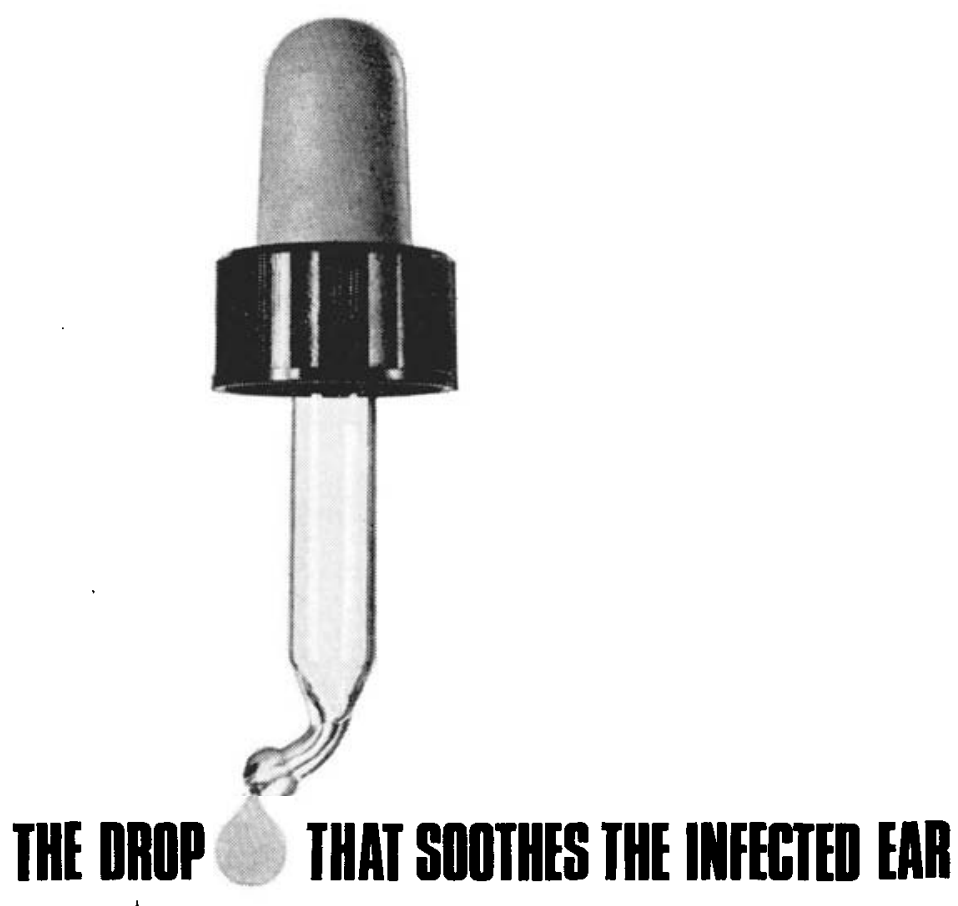

'Otosporin' rapidly destroys virtually all bacteria commonly found in ear infections. reduces irritation, inflammation and pain. 'Otosporin' brand Drops contain polymyxin $B$ sulphate, neomycin sulphate and hydrocortisone in a bland suspension designed to facilitate penetration. Issued in bottles of $5 \mathrm{ml}$.

\section{'OTOSPORIII'} Burroughs Wellcome \& Co. London
(The Wellcome Foundation Ltd.) 


\section{ORBDNIN and its sucgess in Gram-Positive Iniegtions}

\section{Otitis media Otitis externa}

Boils

Carbuncles

Infected dermatoses

Pneumonia Lung abscess Acute bronchitis

Osteomyelitis

Osteitis
Tonsillitis Pharyngitis

Post-operative wound infections Burns

Skin graft protection

Septicaemia

Acute endocarditis

Staphylococcal enterocolitis

Staphylococcal urinary tract infections

Staphylococcal meningitis
ORBENIN (cloxacillin sodium B.P.) is a penicillin active against virtually all Gram-positive organisms, including staphylococci, $\beta$-haemolytic streptococci and pneumococci, irrespective of their resistance to other antibiotics.

It is encouraging that the widespread use of Orbenin in hospitals has not resulted in the emergence of resistant strains.

More than 300 references in the World Literature testify to the excellent clinical results obtained with Orbenin in a wide variety of Gram-positive infections.
Dosage:

Two capsules (500mg.) or one vial (250mg.) q.i.d.

Availability:
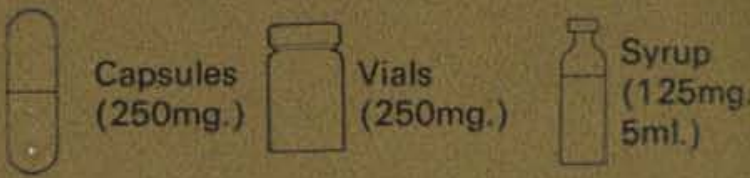

Detailed literature is available on request. 


\section{WHEN A HEARING AID IS RECOMMENDED ONLY AMPLIVOX OFFERS THIS HEARING AID SERVICE}

The design and manufacture of a complete range with individual fitting facilities.

Best of other makes in addition to Amplivox aids-Amplivox hearing aids are ONLY available from Amplivox.

Highest degree of training of any hearing aid organisation.

Master Hearing Aid evaluations.

Expert follow-up and rehabilitation advice.

15 branch offices with while-you-wait service.

FOR YOUR PATIENTS' GREATEST SATISFACTION SPECIFY AMPLIVOX

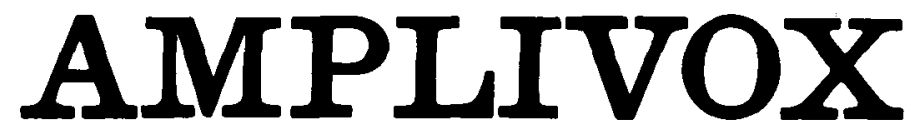

World's most experienced and complete hearing service

\section{AMPLIVOX HEARING ADVISORY SERVICE \\ 80 NEW BOND STREET \\ LONDON, W.1}

Please mention The Journal of Laryngology and Otology when replying to advertisements 


\section{BÉKÉSY \\ ACCESSORY}

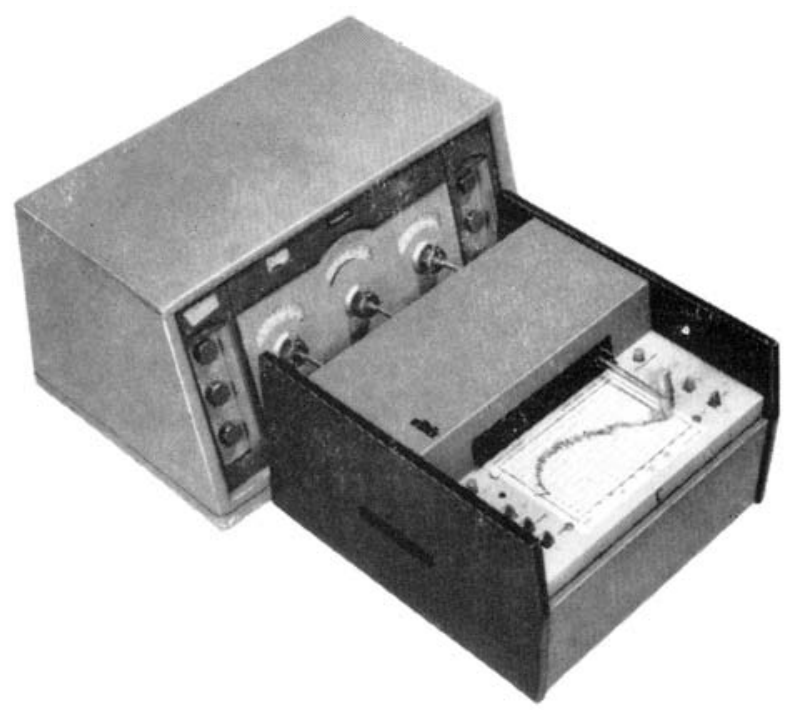

For the very first time a fully automatic unit has been made available for a Clinic Audiometer, making the combined units into a true BÉKÉSY Audiometer.

This automatic accessory is being made for the PETERS SPD/5 CLINIC AUDIOMETER, which has a continuous frequency range and continuously variable attenuation. The result is therefore a true Békésy audiometer.

It can be attached to or detached from the audiometer in under one minute so that the two units together offer the facilities of an advanced clinic audiometer or Békésy audiometry at will.

It can be fitted to any existing SPD/5 Audiometer.

Please write for full details and demonstration to:

\section{ALFRED PETERS \& SONS LIMITED}

51 GELL STREET, SHEFFIELD 3 


\section{ONLY AMPLIVOX provides a complete audiometric service!}

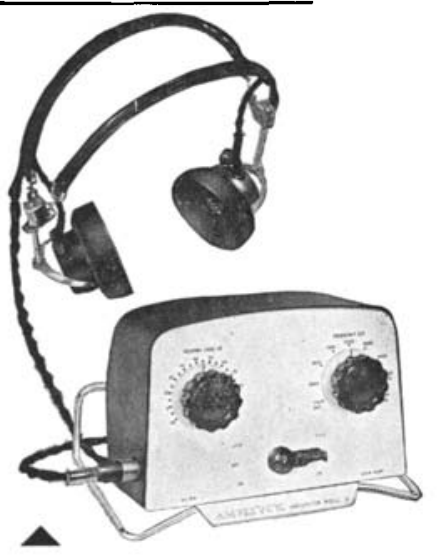

\section{Transistor Audiometers}

with air conduction or air and bone conduction with masking, for hospitals, schools, consulting rooms, industrial medical departments, screening programmes, etc.

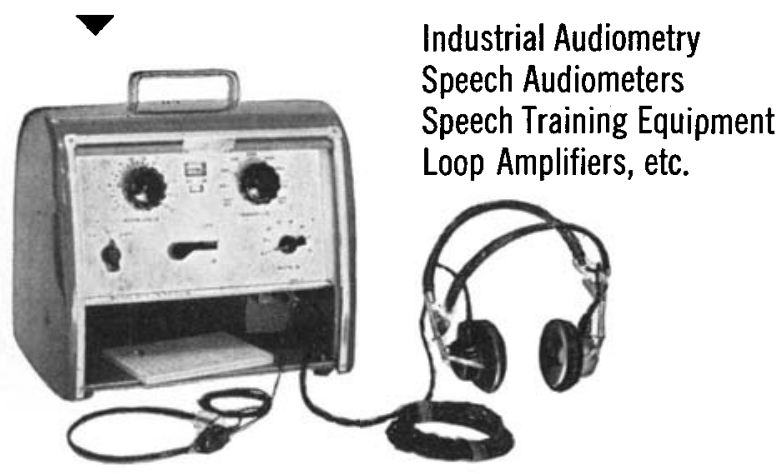

PL US An efficient and speedy calibration service

please write for technical literature to meet your needs

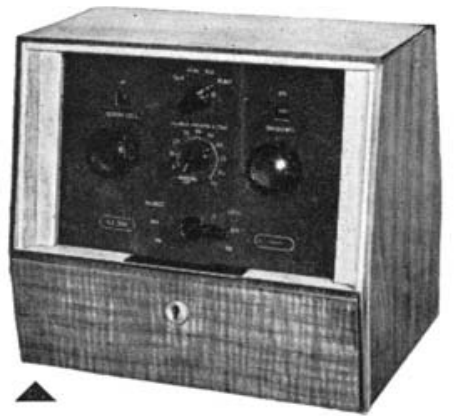

Clinical Audiometers

with narrow band masking for the highest accuracy and extended resolution.

\section{Audiometer Booths}

for ideal testing conditions in hospitals, clinics, factories. Standard and special sizes available.

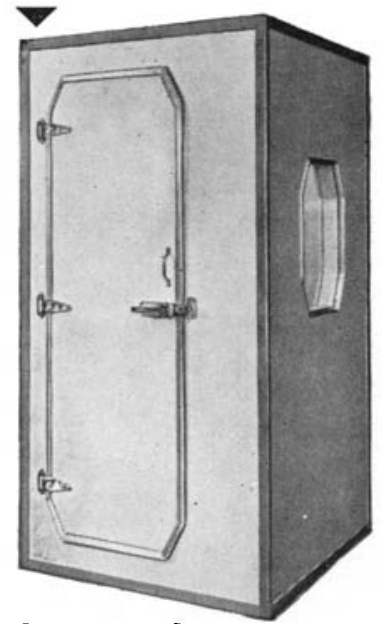

HEARING ADVISORY SERVICE LTD. 80 New Bond Street, London, W.1. Tel: HYDe Park 9888

P'lcase mention The Journal of Laryngology and Otology when replying to advertisements 
Robust construction-high grade components

- Portable, battery operated

- Modern transistor circuitry

- Versatile with many facilities
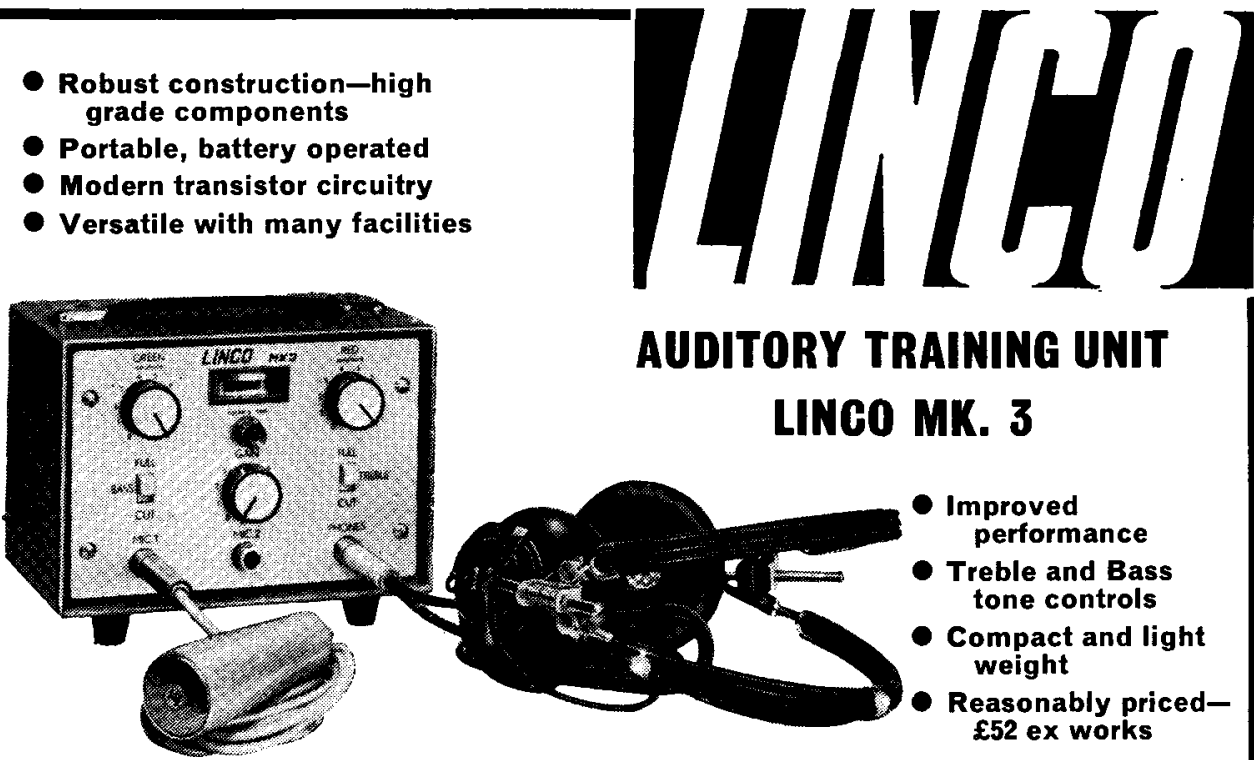

LINGO MK. 3

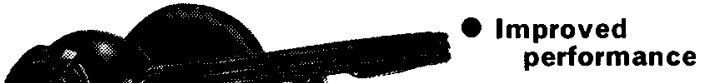
performance

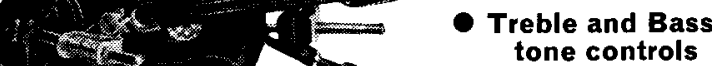
tone controls

Compact and light weight

Reasonably priced$£ 52$ ex works

For further details please write to:

G. C. Johnson, Leyton Instrument Co. Ltd.,

54 Albert Rd., Caversham, Reading, Berks. Reading 72293

\section{THE LARYNGOSCOPE}

A Monthly Journal devoted to the disease of EAR, NOSE AND THROAT

Official organ for the American Laryngological Rhinological and Otological Society

Price $\$ 18.00$ per year Canada $\$ 19.00$ per year Foreign $\$ 19.00$ per year

ESTABLISHED 1896

THEODORE E. WALSH, M.D. EDITOR

\section{SOUTH EUCLID AVENUE SAINT LOUIS MO. 63110.}

Please mention The Journal of Laryngology and Otology when replying to advertisements 


\section{all clear}

\section{in sinusitis, otitis media and coryza}

'Triogesic' provides decongestion with analgesia.

\begin{tabular}{|c|c|c|c|}
\hline & TABLETS & ELIXIR & \\
\hline $\begin{array}{l}\text { Revised } \\
\text { Formula }\end{array}$ & $\begin{array}{c}\text { scored } \\
\text { (per tablet) } \\
\text { Phanylpropanolamine-HCl } 12.5 \mathrm{mg} . \\
\text { Paracetamol B.P. } \quad 500 \mathrm{mg} .\end{array}$ & $\begin{array}{l}\text { cherry flavoured } \\
\text { (per } 5 \mathrm{ml} .) \\
\text { Phenylpropanolamine-HCl } \\
\text { Paracetamol B.P. } \\
\text { Alcohol }(95 \%)\end{array}$ & $\begin{array}{r}3 \mathrm{mg} . \\
125 \mathrm{mg} . \\
0.5 \mathrm{ml} .\end{array}$ \\
\hline Packs & tubes of 30 & bottles of 8 and $20 \mathrm{fl} .02$. & \\
\hline $\begin{array}{l}\text { Basic N.H.S. } \\
\text { Price }\end{array}$ & $3 / 6 \mathrm{~d}$. for 30 tablets & $5 / 10 \mathrm{~d}$. for $8 \mathrm{fl.} 0 z$. & \\
\hline
\end{tabular}

Literature and sample on request. A. Wander Ltd., 42 Upper Grosvenor Street, London W.1
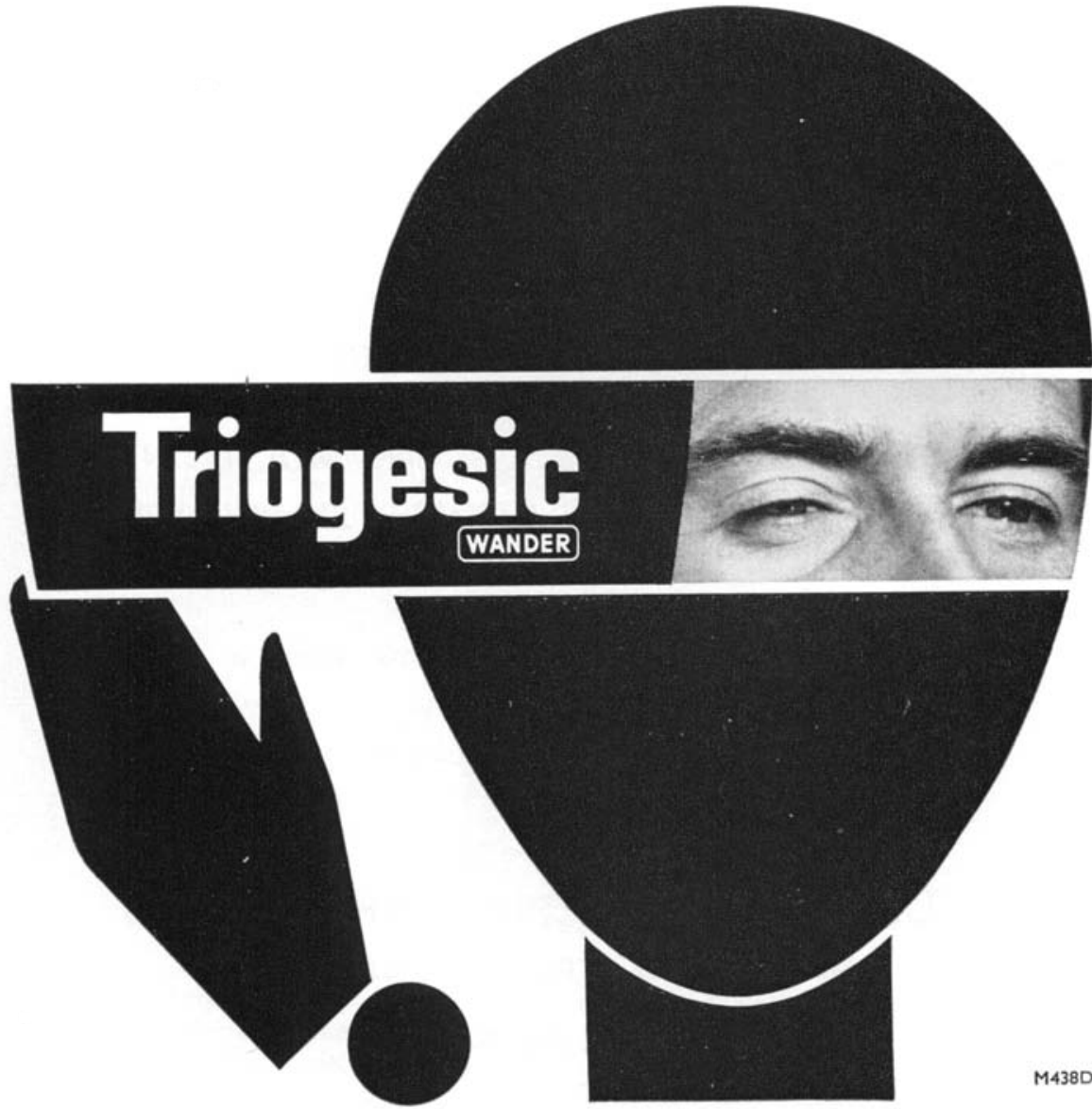

Please mention The Journal of Laryngology and Otology when replying to advertisements 


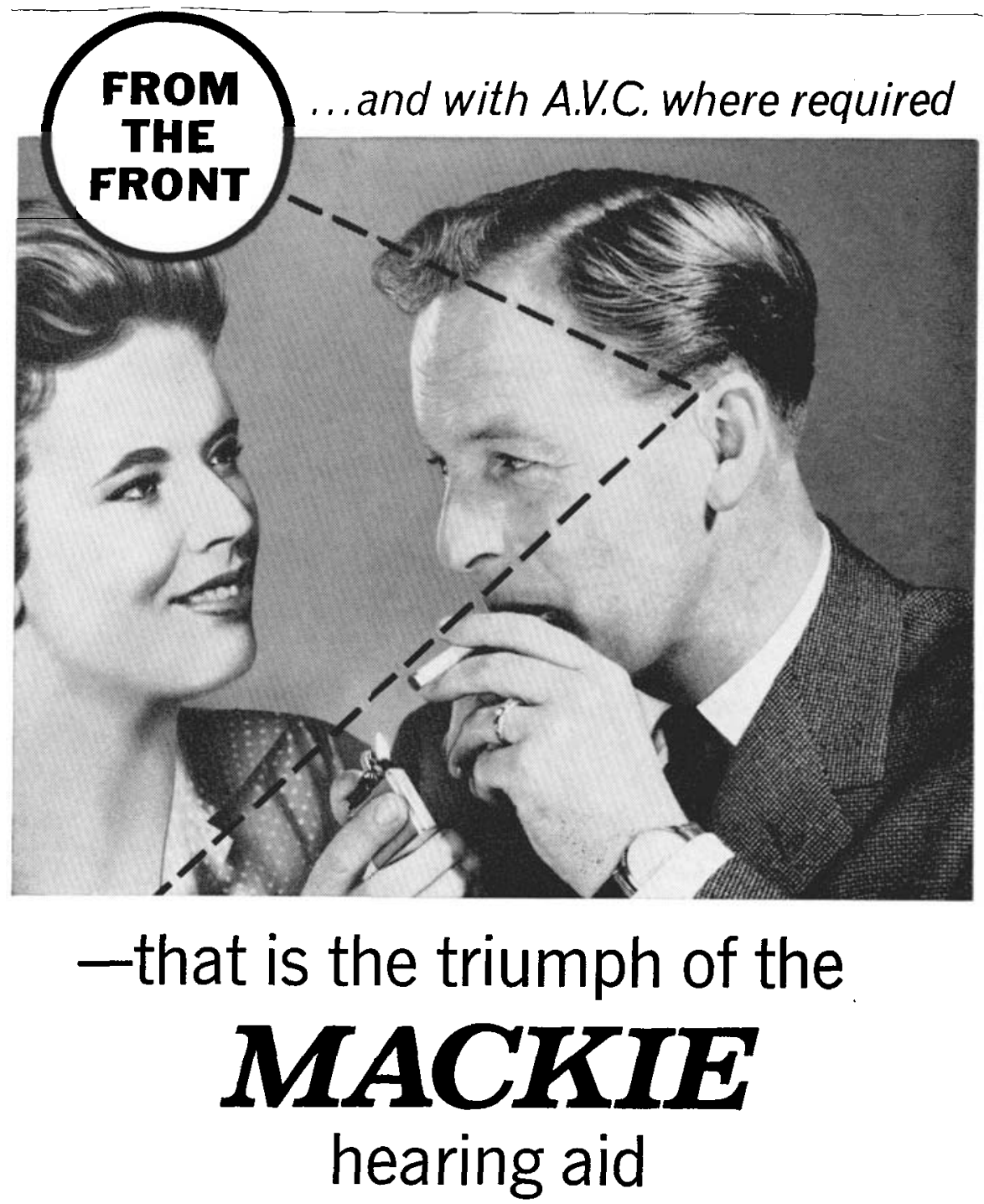

The new Mackie post-aural hearing aid is made in several different circuit versions so that the gain and frequency response can be selected to match the patient's needs; and it is available where required with a unique form of automatic volume control which has proved highly successful in cases of recruitment. The forward pick-up microphone gives maximum intelligibility of speech without background interference.

It is exported to many countries including the United States of America-a tribute to its high quality and advanced design.

In Great Britain it is available for trial by your patients from independent hearing aid dealers in all parts of the country.

MANUFACTURED BY A. G. R. MACKIE LTD. A member of the Bonochord Group of Companies FOR FURTHER DETAILS WRITE TO 48 WELBECK STREET, LONDON WI

Please mention The Journal of Laryngology and Otology when replying to advertisements 
NEW

FOR OTITIS

EXTERNA

AND CHRONIC OTITIS MEDIA

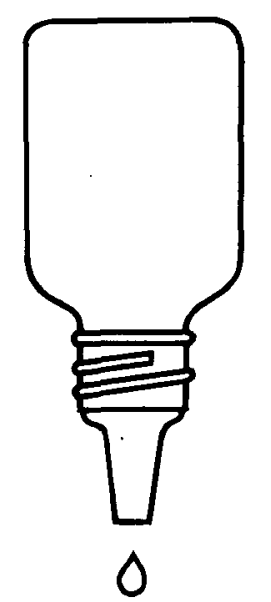

FOR

INFLAMMATION

AND

INFECTION

IN THE EAR

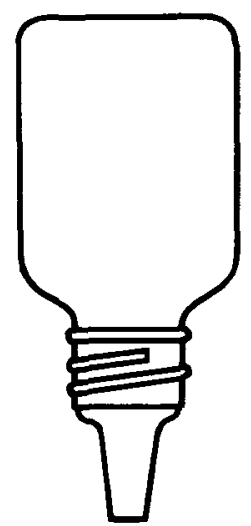

0
ANTI-

INFLAMMATORY

ANTI-

BACTERIAL ANTIFUNGAL

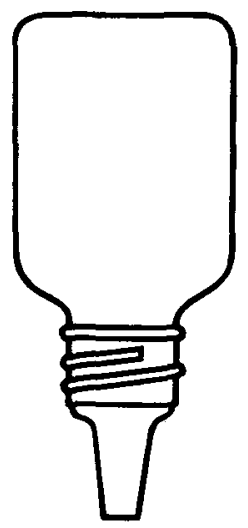

$\diamond$

\section{LOCORTEN- \\ VIOFORM \\ EARDROPS \\ C I B A \\ LOCORTEN- \\ LOCORTEN- \\ VIOFORM \\ EARDROPS \\ $7.5 \mathrm{ml}$, in controlled-drop dispenser}

L.eolt 


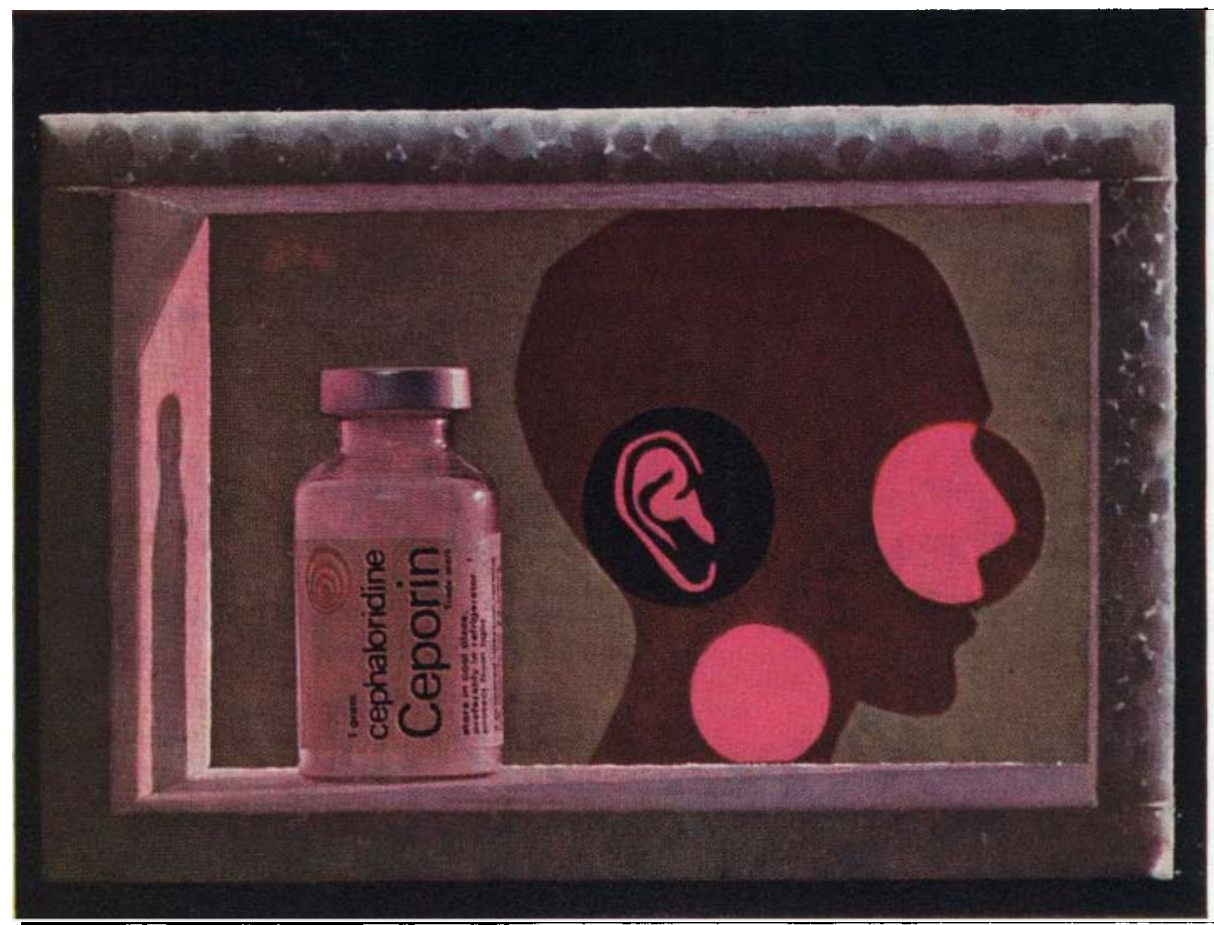

\section{What makes this antibiotic so valuable in the ENT unit?}

\section{Spectrum? \\ Exceptionally broad. It covers most gram-positive organisms-including the penicillin-resistant staphylococci-and many gram-negative organisms.}

\section{Action?}

Intensely bactericidal. It gives a rapid kill of bacteria at or near the minimum inhibitory concentration, especially in the case of gram-negative organisms.

\section{Safety?}

Wide clinical usage has confirmed the laboratory evidence that Ceporin has a remarkably low toxicity. It is usually well tolerated by patients allergic to penicillin.

\section{Clinical record?}

The latest analysis of clinical results obtained with Ceporin shows a total of 131 ENT infections treated : 109 (83\%) responded satisfactorily. There were 28 cases of tonsillitis, of which 24 responded well. The majority of these infections was caused by beta-haemolytic streptococci, but there were several mixed infections involving streptococci, staphylococci and Corynebacterium diphtheriae.
Otitis also responded well. Of the 28 cases treated, 24 responded satisfactorily. Most of these infections were caused by staphylococci but infections involving coliforms, pneumococci, Streptococcus pyogenes, proteus and Haemophilus influenzae were also represented. Often rapid clinical response was obtained with Ceporin after other antibiotics had failed. Conditions which respond well to Ceporin include : mastoiditis, otitis media, sinusitis, quinsy, pharyngeal abscess, and intracranial infections secondary to infected sinuses and mastoiditis.

Because of its three main attributes broad spectrum, bactericidal action and low toxicity-Ceporin has proved valuable for use in place of more toxic drugs or combinations of antibiotics. Presentation Vials containing $250 \mathrm{mg}, 500 \mathrm{mg}$ and $1 \mathrm{gram}$ of cephaloridine, packed singly and in boxes of five.

Ceporin is a Glaxo trade mark

Detailed literature is available from

Glaxo Laboratories Limited

Greenford, Middlesex 
